Article

\title{
Application of LCA Methodology to the Production of Strawberry on Substrates with Peat and Sediments from Ports
}

\author{
Pilar Legua ${ }^{1, *}\left(\mathbb{0}\right.$, Francisca Hernández ${ }^{1}\left(\mathbb{0}\right.$, Francesca Tozzi $^{2}{ }^{2}$, Rafael Martínez-Font ${ }^{1}$, David Jorquera ${ }^{3}$, \\ Caridad Rosique Jiménez ${ }^{4}{ }^{\circledR}$, Edgardo Giordani ${ }^{2}{ }^{\circledR}$, Juan José Martínez-Nicolás ${ }^{1}$ and Pablo Melgarejo ${ }^{1}$ \\ 1 Plant Production and Microbiology Department, Polytechnic School of Orihuela (EPSO), \\ Miguel Hernandez University, Ctra. Beniel Km 3.2, 03312 Orihuela, Alicante, Spain; \\ francisca.hernandez@umh.es (F.H.); rafa.font@umh.es (R.M.-F.); juanjose.martinez@umh.es (J.J.M.-N.); \\ pablo.melgarejo@umh.es (P.M.) \\ 2 Department of Horticulture, University of Florence, 50121 Florence, Italy; francesca.tozzi@unifi.it (F.T.); \\ edgardo.giordani@unifi.it (E.G.) \\ 3 Think Tank InnoTech, Scientific Park of Murcia, Carretera de Madrid Km 388, 30100 Espinardo, Murcia, Spain, \\ djorquera@t3imasd.eu \\ 4 Electromagnetism and Electronics Department, Agroforestry Engineering Area, Campus de Espinardo, \\ University of Murcia, 30100 Espinardo, Murcia, Spain; crosique@um.es \\ * Correspondence: p.legua@umh.es; Tel.: +34-966-749-669
}

\section{check for}

updates

Citation: Legua, P.; Hernández, F.; Tozzi, F.; Martínez-Font, R.; Jorquera, D.; Rosique Jiménez, C.; Giordani, E.; Martínez-Nicolás, J.J.; Melgarejo, P. Application of LCA Methodology to the Production of Strawberry on Substrates with Peat and Sediments from Ports. Sustainability 2021, 13, 6323. https://doi.org/10.3390/ su13116323

Academic Editor: Stefania Nin

Received: 31 March 2021

Accepted: 24 May 2021

Published: 2 June 2021

Publisher's Note: MDPI stays neutral with regard to jurisdictional claims in published maps and institutional affiliations.

Copyright: (c) 2021 by the authors. Licensee MDPI, Basel, Switzerland. This article is an open access article distributed under the terms and conditions of the Creative Commons Attribution (CC BY) license (https:// creativecommons.org/licenses/by/ $4.0 /)$.

\begin{abstract}
The Life Cycle Assessment (LCA) methodology was applied to identify the potential environmental impact of dredged sediments used as growing media for food crops. The dredged sediments used came from Livorno port and were previously phytoremediated. For the assay, strawberry plants (Fragaria x ananassa Duch vr. 'San Andreas') were used. The plants were cultivated on three different substrates (100\% peat, $100 \%$ dredged sediment and $50 \%$ mix peat/sediment) to identify the real impact of the culture media on the growing process. LCA was calculated and analyzed according to ISO 14040:2006 by SimaPro software. ReCipe Midpoint (E) V1.13/Europe Recipe E method was applied. One kilogram of produced strawberry, for each crop media tested, was defined as the functional unit. Eighteen impact categories were selected where Marine Eutrophication (ME), Human Toxicity (HT) and Freshwater Ecotoxicity (FET) were identified as relevant impact categories. The LCA results showed an increase in the environmental impact of strawberry cultivation using $100 \%$ sediment against $100 \%$ peat, due to the decrease in fruit production caused by the sediment. Nevertheless, the decrease in the environmental impact and the fruit production increase identified when the sediment is used mixed $(<50 \%)$ with other substrates. The appropriate use of these substrates would be justified within the context of the circular economy.
\end{abstract}

Keywords: Life Cycle Assessment; dredging sediments; techno-soil; Fragaria

\section{Introduction}

Aiming to maintain the viability of the ports, and guarantee the transit of cargo ships, it is necessary to periodically perform dredging activities. These dredged sediments are often considered contaminated and present an important problem to port management. In this context, different options for the sustainable management of dredged sediments are being studied, proposed and applied such as beneficial use, treatment and/or confined disposal [1]. However, the high specific costs of decontamination treatments mean that in most cases it is not economically sustainable to use these substrates. For this reason, it is necessary that the sediment management options will be specifically identified for each port and that the choice between one alternative or another maintains a sustainability approach that considers economic, environmental and social aspects [2].

In recent years, the European Union has promoted through specific policies the valorization of dredged sediments, and phytoremediation has been presented as an effective low-cost technology for decontaminating marine-dredged sediments, allowing its use as 
techno-soil and as a component of culture media for ornamentals nursery plantations [3,4]. The economic use and revalorization of the treated sediments would facilitate the economic sustainability of decontamination treatments with a significant effect on the overall energy use and its climate impact [5].

As defined by the European Commission for Standardization (CEN), a growing medium (GM) is a material, other than soil in situ (in its original place), in which plants are grown [6] and many types of materials are used in growing media. The most common are peat, pumice, coconut fiber, rice husk and compost [7]. Peat is the main constituent of growing media in the EU and the peat and growing media industry in the EU has a strong significance on three levels: (1) extraction of the raw material, (2) the production of growing media and (3) the usage of growing media in horticulture [8]. There is progressive exhaustion of peatland; therefore, a substitute for peat as a growing substrate is required [9].

The use of bioremediated sediment as part of the culture substrate reduces the impacts that the use of a conventional culture substrate would have. However, it is necessary to consider that although phytoremediation is generally perceived as a sustainable green technology, like any agricultural activity, it can cause many environmental impacts, mainly due to harvesting, the application of fertilizers and pesticides, direct emissions, and the biomass destination [10]. It is, however, important to consider that phytoremediation may influence the function of the mix, and growing media are comparable only if they fulfil the same function [11].

For the professional grower in the horticultural industry, the most important factor is that the growing medium functions well under the given growing conditions [8], and the choice of a growing media composition is limited by technical considerations (e.g., growing medium characteristics, crop requirements, safety, reliability, availability of constituents, price). In substituting a peat-based mix for a peat-free mix, the grower needs to consider whether the crop quality and yield will remain the same. If this is not the case, the growing media will not be comparable because they will not be functionally equivalent. The assessment of the quality of culture media is beyond the scope of this study. This aspect must be taken into account during the analysis and interpretation of the results.

The Life Cycle Assessment (LCA) is a standardized methodology used to investigate the environmental impact of a product, a production process, or a system along its entire cycle of life. It has been widely used to analyze the environmental impacts in agricultural production as well as to compare horticultural growing media based on peat and other media constitutes [11-16]. Among the combination of recommended tools for decision making on sediments and dredged materials is the LCA along with costs, cost and benefit analysis and risk assessment studies [1]. It is a possibility to combine LCA and RA (Risk Assessment) by including ecotoxicological and toxicological parameters in life cycle impact assessment (LCIA) in LCA [8].

The main objective of this study was to analyze the environmental behavior of the use of 'growing media' substrates obtained from port dredged sediments in strawberry production. This work aims to identify the contribution to the impact on the strawberry production system under experimental conditions of the use of phytoremediated dredged sediments as a component of growing media for the cultivation of strawberry 'San Andreas' and compare it with peat as growing media.

\section{Materials and Methods}

In this study, the LCA analysis was conducted according to the ISO 14040:2006 guidelines [17]. The study was divided into four steps: (1) goal and scope definition; (2) inventory analysis; (3) impact assessment and (4) interpretation (included in the section of this paper 'Results and Discussions'). The type of selected LCA for this study is a 'cradle to gate $\mathrm{LCA}^{\prime}$, meaning the whole production process is analyzed and all inputs (raw material and energy consumption) and their interactions are considered. This is a Streamlined LCA, which has been selected because of the large amount of data needed to do a cradle-to-grave evaluation [18]. The main LCA result is a quantified environmental impact through stan- 
dardized 'Impact Category', and the categories most used are Global Warming Potential, Acidification, Eutrophication, Ozone Layer Depletion and Human Toxicity.

\subsection{Goal and Scope and Functional Unit}

Functional Unit (FU): The functional unit provides the reference to which all other data in the product systems are normalized. Previous LCA studies for growing media (GM) used diverse FU such as $1 \mathrm{~m}^{3} \mathrm{GM}$ and 1 planta or GM amount employed. Note that these works focused on the LCA system analysis from an ornamental plants production point of view [11,19-21]. Since the GM characteristics could affect the yield crop, therefore, to the main function of the system analyzed, in this case, $1 \mathrm{~kg}$ of fruit produced at the farm has been selected as the FU [22]. The adequacy of the FU selected is based on previous works developed by the same research group, where it was reported that the GM used did not affect the fruit quality and/or composition $[23,24]$. Therefore, the $\mathrm{kg}$ of fruits represents an equivalent function in all the alternative systems considered (Figure 1).

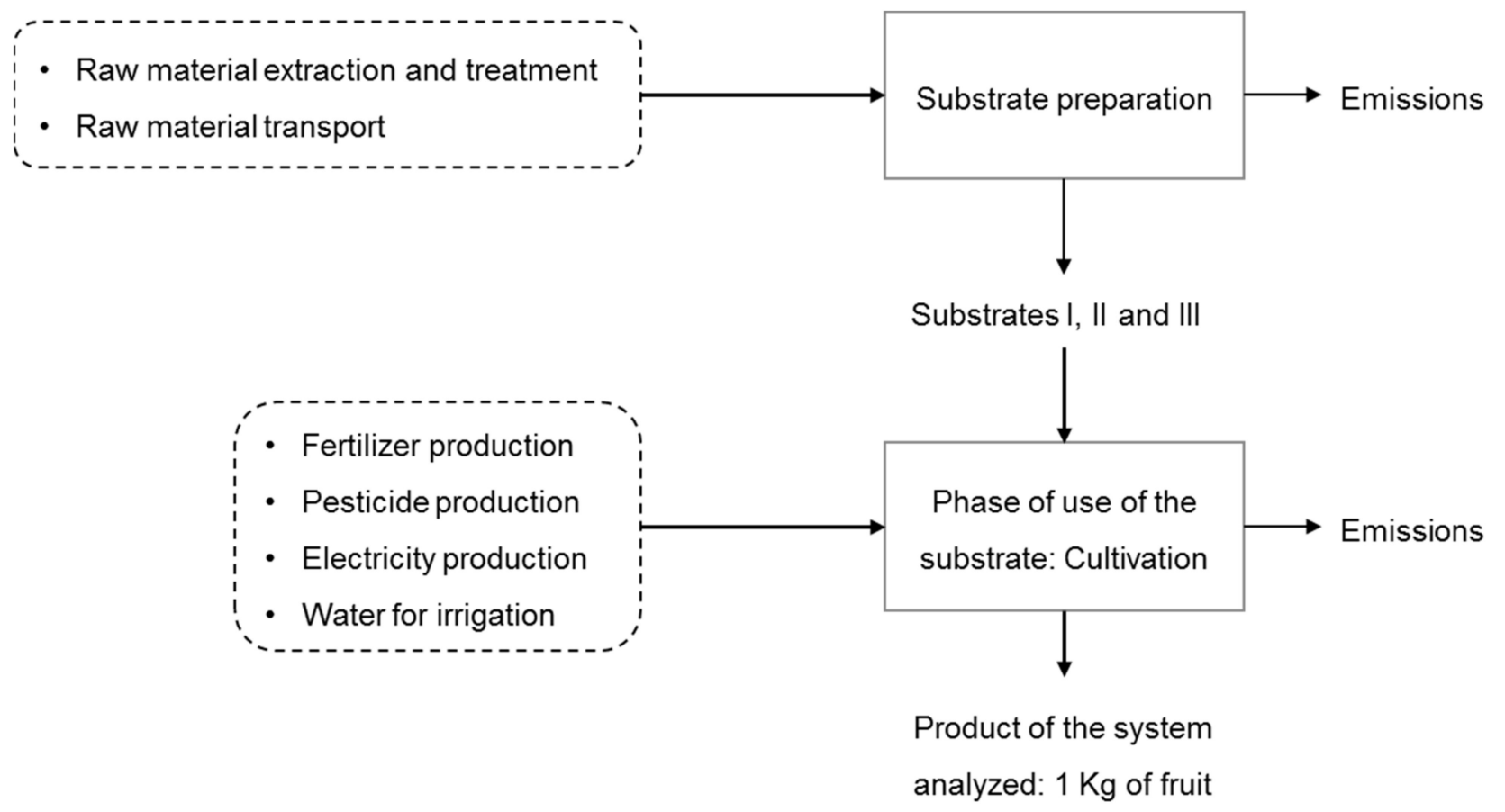

Figure 1. System boundaries for the life cycle assessment of strawberry.

\subsection{Selection of the Strawberry Variety for Cultivation and LCA Study}

The strawberry 'San Andreas' variety was chosen as a representative plant for the realization of the LCA analysis. This decision was based on their better adaptation to the growing conditions using dredged marine sediments mixed with peat when compared with other strawberry varieties, such as 'Camarosa' and 'Monterrey', identified in previous work [9].

\subsection{Study System Description}

The raw material used for the growing media in this study was peat and dredged sediments from the port of Livorno (Italy).

The dredged sediment treatment consisted of two consecutive phases: (a) partial decontamination of the sediments by phytoremediation over three years; and (b) additional landfarming process over three months to make the sediments suitable for the subsequent horticulture trials. The process was financed by the European project AGRIPORT Agricultural Reuse of Polluted Dredged Sediments ( ${ }^{\circ}$ ECO/08/239065/S12.532262) [25]. 
In general terms for the LCA methodology, $80 \mathrm{~m}^{3}$ of sediments, previously mixed with $24 \mathrm{~m}^{3}$ of soil, were placed in a sealed basin ( $20 \mathrm{~m}$ length, $5 \mathrm{~m}$ width and $1.3 \mathrm{~m}$ depth), located in Livorno port. A dose of $4 \mathrm{~kg} \mathrm{~m}^{-2}$ of compost was uniformly added on top of the soil-sediment mixture and was incorporated into the top $20 \mathrm{~cm}$ layer of sediment by a standard medium size agricultural tractor. The total fuel consumed during this phase was 56 L. Dredged sediment remediation details and results are explained by Doni et al. [25]. The characterization of sediments and peat is collected in Table 1.

Table 1. Initial growing media characterization. Mean value \pm standard deviation.

\begin{tabular}{|c|c|c|c|}
\hline Parameter & Sediment before Landfarming * & Peat ** & Sediment after Landfarming $* * *$ \\
\hline Bulk density $\left(\mathrm{kg} \mathrm{m}^{-3}\right)$ & $1012 \pm 74$ & $238 \pm 26$ & $1290 \pm 120$ \\
\hline $\mathrm{pH}\left(\mathrm{H}_{2} \mathrm{O}\right)$ & $7.88 \pm 0.03$ & $4.55 \pm 0.08$ & $8.16 \pm 0.06$ \\
\hline $\mathrm{EC}\left(\mathrm{mS} \mathrm{cm}^{-1}\right)$ & $1.08 \pm 0.09$ & $0.38 \pm 0.06$ & $0.45 \pm 0.09$ \\
\hline Total C $\left(\mathrm{g} \mathrm{kg}^{-1}\right)$ & $27.30 \pm 2.40$ & $893.00 \pm 24.90$ & ND \\
\hline Organic C $\left(\mathrm{g} \mathrm{kg}^{-1}\right)$ & $17.30 \pm 2.30$ & $524.9 \pm 2.20$ & $23.00 \pm 0.70$ \\
\hline Inorganic $C\left(\mathrm{~g} \mathrm{~kg}^{-1}\right)$ & $11.90 \pm 2.00$ & ND & ND \\
\hline Total N $\left(\mathrm{g} \mathrm{kg}^{-1}\right)$ & $1.22 \pm 0.11$ & $2.50 \pm 0.24$ & $0.18 \pm 0.01$ \\
\hline Total P $\left(\mathrm{g} \mathrm{kg}^{-1}\right)$ & $51.30 \pm 3.78$ & $7.96 \pm 1.30$ & $577.00 \pm 33.00$ \\
\hline Available P (mg kg $\left.{ }^{-1}\right)$ & $2.43 \pm 0.15$ & $0.46 \pm 0.06$ & $14.80 \pm 3.10$ \\
\hline $\mathrm{Ca}\left(\mathrm{g} \mathrm{kg}^{-1}\right)$ & $27.30 \pm 3.10$ & $0.43 \pm 0.05 c$ & ND \\
\hline $\operatorname{Mg}\left(\mathrm{g} \mathrm{kg}^{-1}\right)$ & $16.2 \pm 1.5$ & $0.50 \pm 0.14$ & ND \\
\hline $\mathrm{Cd}\left(\mathrm{mg} \mathrm{kg}^{-1}\right)$ & $1.52 \pm 0.27$ & $0.49 \pm 0.09$ & $<\mathrm{LOD}$ \\
\hline $\mathrm{Cr}\left(\mathrm{mg} \mathrm{kg}^{-1}\right)$ & $59.30 \pm 5.50$ & $34.10 \pm 17.00$ & $59.10 \pm 2.60$ \\
\hline $\mathrm{Cu}\left(\mathrm{mg} \mathrm{kg}^{-1}\right)$ & $82.10 \pm 5.60$ & $126.60 \pm 20.00$ & $37.50 \pm 3.50$ \\
\hline $\mathrm{Ni}\left(\mathrm{mg} \mathrm{kg}^{-1}\right)$ & $67.10 \pm 4.00$ & $2.24 \pm 0.79$ & $37.50 \pm 4.50$ \\
\hline $\mathrm{Pb}\left(\mathrm{mg} \mathrm{kg}^{-1}\right)$ & $65.10 \pm 2.90$ & $9.14 \pm 1.30$ & $35.00 \pm 3.50$ \\
\hline $\mathrm{Zn}\left(\mathrm{mg} \mathrm{kg}^{-1}\right)$ & $284.60 \pm 24.00$ & $9.15 \pm 1.90$ & $268.00 \pm 28.00$ \\
\hline \multicolumn{4}{|c|}{ Organic Contaminants } \\
\hline $\mathrm{C}>12\left(\mathrm{mg} \mathrm{kg}^{-1}\right)$ & - & - & $286.00 \pm 26.00$ \\
\hline$C<12$ & - & - & $<\mathrm{LOD}$ \\
\hline PHAs & - & - & $52.70 \pm 6.13$ \\
\hline PCB & - & - & 0.04 \\
\hline
\end{tabular}

Adapted from * Masciandaro et al., 2014 [3] and ** Mattei et al., 2018 [19]; *** Sediment used for strawberry production studied; ND: Non detected; LOD: Limit of detection; PHA: Polyhydroxyalkanoates; PCB: Polychlorinated biphenyls.

The cultivation was conducted from 2016 to 2017 in a Miguel Hernández University experimental plot located in Orihuela, SE Spain. Three alternatives of substrates were compared: (SI) 100\% Peat, (SII) 50\% peat and 50\% dredged remediated sediment and (SIII) $100 \%$ dredged remediated sediment. The total amount of 'San Andreas' strawberry plants (Fragaria $x$ ananassa Duch.) used in the trial was 204 (68 plants for each type of substrate). The plantation was carried out in 14 rectangular containers $(150 \mathrm{~cm} \times 30 \mathrm{~cm} \times 15 \mathrm{~cm}$ each) of High-Density Poly Ethylene (HDPE). Crop irrigation requirements were scheduled according to tensiometers values (Watermark ${ }^{\circledR}$ probes), placed at three different locations per treatment, in the root area at $10 \mathrm{~cm}$ deep between two drippers. The same fertigation solution was used in all the treatments (Table 2). Fertigation water was supplied through a drip irrigation system, one pipeline for each container, with one drip per plant $\left(2 \mathrm{~L} \mathrm{~h}^{-1}\right)$. A total of $39.9 \mathrm{~L}$ per plant of fertilizer solution based on $\mathrm{KNO}_{3}, \mathrm{NH}_{4} \mathrm{NO}_{3}, \mathrm{~K}_{2} \mathrm{SO}_{4}, \mathrm{HNO}_{3}$, $\mathrm{H}_{3} \mathrm{PO}_{4}$ and microelements at the standard concentration were applied in the studied cycle.

The final total yield obtained for each substrate tested (68 plants for each substrate) during the studied crop campaign (2016-2017) was $27.4 \mathrm{~kg}$ for SI, $17.4 \mathrm{~kg}$ for SII and $6.9 \mathrm{~kg}$ for SIII. 
During the experiment, the following input data were collected: volume of growing media, energy consumption, electricity (including programmer, remover and pumps for irrigation), water and fertilizer consumption and pesticides. Pesticide consumption was allocated according to the number of plants in each substrate. The outputs determined were fruit harvested $(\mathrm{kg})$, leachate volume $(\mathrm{L})$ and the composition of leachate was analyzed.

Table 2. Compositional specification of the fertigation used for strawberry production.

\begin{tabular}{cc}
\hline Compound & g L $^{-1}$ \\
\hline $\mathrm{KNO}_{3}$ & 0.939 \\
$\mathrm{NH}_{4} \mathrm{NO}_{3}$ & 0.040 \\
$\mathrm{~K}_{2} \mathrm{SO}_{4}$ & 0.097 \\
$\mathrm{HNO}_{3}$ & 0.015 \\
$\mathrm{H}_{3} \mathrm{PO}_{4}$ & 0.126 \\
Micronutrient complex & 0.030 \\
\hline
\end{tabular}

\subsection{Inventory}

\subsubsection{Raw Materials to Growing Media}

To model the sediment extraction phase (Table 3), the data provided by Kemp [26] were used. The AGRIPORT and HORTISED LIFE projects and bibliographic data were used to include the date of phytoremediation and landfarming [9,24]. The data extraction of peat is provided by Ecoinvent and quantifies the directly affected area, the electricity requirements and the diesel used for the mining operation and the extraction. Regarding the growing media production (substrate preparation), the mixing activities (e.g., energy, buildings and packaging) were considered equivalent for all the growing media; consequently, they were not taken into account since they are equal following Quantis [11]. The energy and material requirements for the production of both the peat and dredged remediated sediments used for the preparation of the growing media included in this study were considered. The peat inventory data provided by Ecoinvent has been modified to eliminate the infrastructure, distribution and packaging processes to make equivalent the depth of the data used for both raw materials.

Table 3. Energy inputs for 1 ton of dredged sediment considered for the LCA study. The inputs were estimated according to Kemp [26].

\begin{tabular}{ccc}
\hline Process & Mean Value \pm Standard Deviation & Unit \\
\hline Dredged & $18.0 \pm 9.0$ & MJ \\
Transport to the wharf & $0.7875 \pm 0.3$ & MJ \\
Unloading & $7.2 \pm 0.9$ & MJ \\
Aggregate processing & 1.51 & $\mathrm{kWh}$ \\
\hline
\end{tabular}

\subsubsection{Phase of Use of Substrate}

The main inputs and outputs considered in this phase are presented in Table 4. Due to their long life span, the contribution of farm structures to the environmental impact was always considered not important and some authors suggest not including such input in future research and therefore will not be considered in this study [7]. The volume of leachate and the composition (Table 5) have been used to calculate the amount of emission of heavy metals, phosphate and nitrate attributable to $1 \mathrm{~kg}$ of strawberries in the modelling of the strawberry production system using Sima Pro software. The input of HDPE (HighDensity Poly Ethylene) was calculated according to the dimensions of the containers, the number of containers used in the test and the information provided by the manufacturers. The packaging of fertilizer and pesticides are not considered. 
Table 4. Main normalized Inventory data for the three crop-growing system alternatives concerning the functional unit ( $1 \mathrm{~kg}$ of 'San Andreas' strawberry product). Numbers may not add up to the sum due to the round-up.

\begin{tabular}{cccc}
\hline & & Substrates & SIII \\
\hline Inputs & SI & SII & 1.04 \\
Energy $(\mathrm{kWh})$ & 0.291 & 0.421 & 289.140 \\
Fertigation $(\mathrm{L})$ & 99.025 & 128 & 8.063 \\
Pesticides $(\mathrm{mg})$ & 2.009 & 31.18 & 1.052 \\
Deltametrin $(\mathrm{mg})$ & 0.262 & 0.415 & 7.011 \\
Imidacroplid $(\mathrm{mg})$ & 1.747 & 2.765 & 0.373 \\
HDPE $(\mathrm{kg})$ & 0.094 & 0.147 & 0.110 \\
Grown media $\left(\mathrm{m}^{3}\right)$ & 0.028 & 0.043 & - \\
Peat $\left(\mathrm{m}^{3}\right)$ & 0.028 & 0.022 & 0.110 \\
Sediment $\left(\mathrm{m}^{3}\right)$ & - & 0.022 & SIII \\
\hline Outputs & $\mathrm{SI}$ & SII & 1 \\
Strawberry $(\mathrm{kg})$ & 1 & 1 & 53.176 \\
Leachate volume $(\mathrm{L})$ & 12.238 & 17.704 & 0.427 \\
$\mathrm{~N}_{2} \mathrm{O}$ (g) to air $(\mathrm{g})$ & 0.146 & 0.189 & 5.439 \\
$\mathrm{NH}_{3}$ to air $(\mathrm{g})$ & 1.863 & 2.408 & \\
\hline
\end{tabular}

Table 5. Leachate chemical composition during the two strawberry production campaigns developed during the years 2016 and 2017.

\begin{tabular}{|c|c|c|}
\hline & First Year of Cultivation (2016) & Second Year of Cultivation (2017) \\
\hline \multicolumn{3}{|c|}{ Chemical Compound $\left(\mathrm{mg} \mathrm{L}^{-1}\right)$} \\
\hline Acetochlor & 0.012 & - \\
\hline Anthraquinone & 0.00014 & - \\
\hline Flutriafol & 0.00006 & - \\
\hline Metalaxyl (+Metalaxyl-M) & 0.0002 & - \\
\hline Simazine & 0.00053 & - \\
\hline Acenaphthylene & - & 0.000024 \\
\hline Phenanthrene & - & 0.00003 \\
\hline Sodium $(\mathrm{Na})$ & 117 & 105 \\
\hline Potassium (K) & 310 & 139 \\
\hline Calcium (Ca) & 198 & 142 \\
\hline Magnesium (Mg) & 49.4 & 35.5 \\
\hline Boron (B) & 0.791 & 0.636 \\
\hline Chlorides $\left(\mathrm{Cl}^{-}\right)$ & 214 & 180 \\
\hline Sulphates $\left(\mathrm{SO}_{4}\right)$ & 310 & 259 \\
\hline Carbonates $\left(\mathrm{CO}_{3}{ }^{2-}\right)$ & $<5.00$ & $<5.00$ \\
\hline Bicarbonates $\left(\mathrm{HCO}_{3}{ }^{-}\right)$ & 105 & 108 \\
\hline Nitrates $\left(\mathrm{NO}_{3}\right)$ & 681 & 346 \\
\hline Ammonia nitrogen $\left(\mathrm{NH}_{4}\right)$ & 0.187 & 1.85 \\
\hline Phosphate $\left(\mathrm{H}_{2} \mathrm{PO}_{4}^{-}\right)$ & 5.4 & 26 \\
\hline \multicolumn{3}{|c|}{ Chemical Compound $\left(\mu \mathrm{g} \mathrm{L}^{-1}\right)$} \\
\hline Manganese (Mn) & 103 & 180 \\
\hline Iron $(\mathrm{Fe})$ & 457 & 3970 \\
\hline Zinc (Zn) & 774 & 435 \\
\hline Copper $(\mathrm{Cu})$ & 127 & 158 \\
\hline Molybdenum (Mo) & 74.4 & 50.9 \\
\hline Lead $(\mathrm{Pb})$ & 7.8 & $<2.00$ \\
\hline Chromium (Cr) & $<10.00$ & $<10.00$ \\
\hline Nickel (Ni) & 24 & 10.2 \\
\hline Cadmium (Cd) & 12.1 & 14.4 \\
\hline Mercury (Hg) & $<0.200$ & 12.6 \\
\hline Arsenic (As) & - & - \\
\hline Selenium (Se) & - & - \\
\hline
\end{tabular}

Values indicated by $<$ indicate concentrations below the detection limits. 
The approach of the LCI (Life Cycle Inventory) database Ecoinvent is used to calculate the direct emissions of pesticides. This approach is based on an ecosphere-technosphere boundary located between the nozzles of the spraying equipment and the soil of the agricultural field [27]. No target processes are considered before the emission into the environment. In this approach, it is assumed that $100 \%$ of the pesticide mass applied is emitted to the environment, in our case, to the agricultural land.

The direct emissions from strawberry production into the air were (a) the emission of ammonia $\left(\mathrm{NH}_{3}\right)$ and (b) $\mathrm{NO}_{2}$ emission from the degradation of mineral fertilization.

The emission of ammonia $\left(\mathrm{NH}_{3}\right)$ was calculated using the specific emission factor (EF) supplied by EMEP/EEA [28] for the different types of fertilizers and taking into account the $\mathrm{pH}$ of the substrate. The EF selected was $0.030 \mathrm{~kg} \mathrm{~N} \mathrm{~kg}^{-1} \mathrm{~N}$ and the emission is calculated as follows: $\mathrm{NH}_{3}=17 / 4 \times \mathrm{EF} \times \mathrm{Nmin} ; \mathrm{NH}_{3}=$ ammonia emission after mineral fertilizer application $\left(\mathrm{kg} \mathrm{NH}_{3}\right) ; \mathrm{Nmin}=$ mineral fertilizer application $(\mathrm{kg} \mathrm{N})$. On the other hand, $\mathrm{NO}_{2}$ emission from the degradation of mineral fertilization was calculated in accordance with the IPCC [29] as the quantity of $\mathrm{N}(\mathrm{kg})$ used $\times 0.01$. The rest of the emissions, including nitrate leaching, phosphate leaching and heavy metal emissions to agricultural soil have been obtained in the experiment [23]. Other possible inputs/outputs have not been considered due to the data gap.

To incorporate the impact due to the production of inputs, the Ecoinvent 3 inventory database [30] and bibliographic data have been used. Data obtained from Ecoinvent were: water, unspecified natural origin; potassium nitrate; ammonium nitrate, as N; potassium sulfate, as $\mathrm{K}_{2} \mathrm{O}$; phosphoric acid, fertilizer grade; pesticide, unspecified production; electricity grid mix $1 \mathrm{kV}-60 \mathrm{kV}$ ES (specific for the Spanish electrical supply characteristics; a Boypi hydraulic pump Model MH-M 230 V/700 W/3.04 A was used and considered); and poly ethylene production. This inventory data was incorporated into the calculation with the help of Sima Pro software.

\subsection{Life Cycle Impact Assessment}

The method used to calculate the potential impacts was ReCiPe Midpoint (E) V1.13/Europe Recipe E. The calculation was made with the help of Sima Pro software. The Impacts Categories included are indicated in Table 6.

Table 6. Impacts of $1 \mathrm{~kg}$ of 'San Andreas' strawberries grown on SI, SII and SIII. Method: ReCiPe Midpoint (E) V1.13/Europe Recipe E/Characterization.

\begin{tabular}{|c|c|c|c|c|}
\hline \multirow[b]{2}{*}{ Impact Category (IC) } & \multirow[b]{2}{*}{ Unit } & \multicolumn{3}{|c|}{ Substrates } \\
\hline & & SI & SII & SIII \\
\hline Climate change $(C C)$ & $\mathrm{kg} \mathrm{CO}_{2} \mathrm{eq}$ & $6.550 \times 10^{-1}$ & $9.370 \times 10^{-1}$ & 2.238 \\
\hline Ozone depletion (OD) & $\mathrm{kg}$ CFC-11 eq & $6.819 \times 10^{-8}$ & $8.823 \times 10^{-8}$ & $1.941 \times 10^{-7}$ \\
\hline Terrestrial acidification (TA) & $\mathrm{kg} \mathrm{SO}_{2} \mathrm{eq}$ & $3.586 \times 10^{-3}$ & $5.219 \times 10^{-3}$ & $1.277 \times 10^{-2}$ \\
\hline Freshwater eutrophication (FE) & $\mathrm{kg} P$ eq & $2.132 \times 10^{-4}$ & $2.773 \times 10^{-4}$ & $6.712 \times 10^{-4}$ \\
\hline Marine eutrophication (ME) & $\mathrm{kg} \mathrm{N} \mathrm{eq}$ & $3.545 \times 10^{-4}$ & $5.981 \times 10^{-4}$ & $1.716 \times 10^{-3}$ \\
\hline Human toxicity $(\mathrm{HT})$ & kg 1,4-DB eq & 4.356 & 5.480 & $1.128 \times 10^{1}$ \\
\hline Photochemical oxidant formation (POF) & kg NMVOC & $2.363 \times 10^{-3}$ & $3.729 \times 10^{-3}$ & $9.766 \times 10^{-3}$ \\
\hline Particulate matter formation (PMF) & kg PM10 eq & $1.261 \times 10^{-3}$ & $1.726 \times 10^{-3}$ & $3.902 \times 10^{-3}$ \\
\hline Terrestrial ecotoxicity (TE) & $\mathrm{kg} 1,4-\mathrm{DB}$ eq & $1.124 \times 10^{-3}$ & $2.272 \times 10^{-3}$ & $7.557 \times 10^{-3}$ \\
\hline Freshwater ecotoxicity (FET) & kg 1,4-DB eq & $2.252 \times 10^{-3}$ & $3.019 \times 10^{-3}$ & $6.659 \times 10^{-3}$ \\
\hline Marine ecotoxicity (ME) & kg 1,4-DB eq & 3.267 & 4.103 & 8.258 \\
\hline Ionising radiation (IR) & kBq U235 eq & $5.103 \times 10^{-2}$ & $7.809 \times 10^{-2}$ & $2.012 \times 10^{-1}$ \\
\hline Agricultural land occupation (ALO) & $\mathrm{m}^{2} \mathrm{a}$ & $9.659 \times 10^{-3}$ & $4.646 \times 10^{-2}$ & $1.986 \times 10^{-1}$ \\
\hline Urban land occupation (ULO) & $\mathrm{m}^{2} \mathrm{a}$ & $1.358 \times 10^{-3}$ & $2.092 \times 10^{-3}$ & $5.447 \times 10^{-3}$ \\
\hline Natural land transformation (NLT) & $\mathrm{m}^{2}$ & $6.711 \times 10^{-6}$ & $5.465 \times 10^{-5}$ & $2.511 \times 10^{-4}$ \\
\hline Water depletion (WD) & $\mathrm{m}^{3}$ & $1.521 \times 10^{-1}$ & $2.097 \times 10^{-1}$ & $4.987 \times 10^{-1}$ \\
\hline Metal depletion (MD) & $\mathrm{kg}$ Fe eq & $2.432 \times 10^{-3}$ & $6.024 \times 10^{-3}$ & $2.137 \times 10^{-2}$ \\
\hline Fossil depletion (FD) & $\mathrm{kg}$ oil eq & $2.859 \times 10^{-1}$ & $4.232 \times 10^{-1}$ & 1.032 \\
\hline
\end{tabular}




\section{Results and Discussion}

\subsection{Inventory Analysis}

Regarding the functional unit, all the inputs and outputs turn out to be larger in SIII (dredged sediment treated) than in SII (mixture), and these, in turn, are greater than those of the production in SI (peat) (Table 4). Although the global water consumptions in SI with peat is superior to SII and SIII, when these are analyzed from the point of view of the LCA, that is, normalized to the functional unit (Table 4), it is verified that the behavior of the production of 'San Andreas' strawberry under SI is the one that presents a better environmental behavior since it corresponds with a lower demand of this input per kilogram of fruit produced. The strawberry production obtained in SII and SIII is lower than that obtained in SI. Therefore, using water input per plant or per unit of planted area as an environmental indicator would not adequately represent the impacts attributable to water consumption in fruit production.

The amount of leachate per functional unit is lower in SI than in SII, and the greatest volumes of leachate are obtained with SIII. The high phosphorus (P) content of the sediment used (Table 1) is one of the causes of the increase in the impact in the eutrophication category in the production of strawberries in SII and SIII.

The addition of sediment to the conventional substrate (in substrate II or in substrate III) presents a higher energy consumption per $\mathrm{kg}$ of strawberries produced compared to substrate I. A greater amount of inputs and outputs to the environment concerning the functional unit can be reflected in a greater impact on the life cycle.

\subsection{Impact Evaluation}

Total impact in each Impact Category (IC) considered for the production of $1 \mathrm{~kg}$ of 'San Andreas' strawberry (for each type of substrate) is presented in Table 6. In addition, the impact results are presented as a percentage of the greatest impact in each category (Figure 2). The impacts of strawberry production grown in SI are between $10 \%$ and $20 \%$ lower than those of strawberries grown in SII. This seems to indicate that including 50\% sediment in the GM under the conditions of the analysis represents an increase between $10 \%$ and $20 \%$ of the environmental impact, depending on the category of impact considered. The impact of the production of $1 \mathrm{~kg}$ of fruit grown in SIII turns out to be $60 \%$ to $92 \%$ higher than the production in SI depending on the IC considered. The infrastructure processes have been excluded from the impact calculation.

The categories that have shown the most weight in the global impact of 'San Andreas' strawberry $\mathrm{kg}$ (marine eutrophication, human toxicity and freshwater eutrophication) have been identified applying Europe E Recipe Normalization factors. They are followed in importance by freshwater ecotoxicity, terrestrial acidification, and climate change. Therefore, in the contribution analysis, we will focus mainly on these.

\subsection{Contribution Assessment}

To identify the elements of the life cycle of the production of $1 \mathrm{~kg}$ of 'San Andreas' strawberries that have more weight in the global impact, a contribution analysis has been carried out with the help of the Sima Pro software by using a cut-off value of $1 \%$. In this section, each element considered in the LCA is investigated individually.

The impact contribution analysis is performed using the ReCiPe method. The percentage of contribution of each subsystem of the Life Cycle to each IC is presented in Table 7.

The substrate contributes $27.65 \%$ to the total impact on marine eutrophication (ME), with the contribution of peat at $3.5 \%$ and that of SIII at $24.1 \%$. The compost used to prepare the sediment accounts for $21.5 \%$ of its contribution.

In human toxicity (HT), fertilizers $(56.8 \%)$ and substrate $(32 \%)$ are the elements with the highest contribution to this impact category. These results are in agreement with the data reported by Huijbregts et al. [31]. In this case, peat (22\%) is the element that contributes the most to the HT of the substrate. 


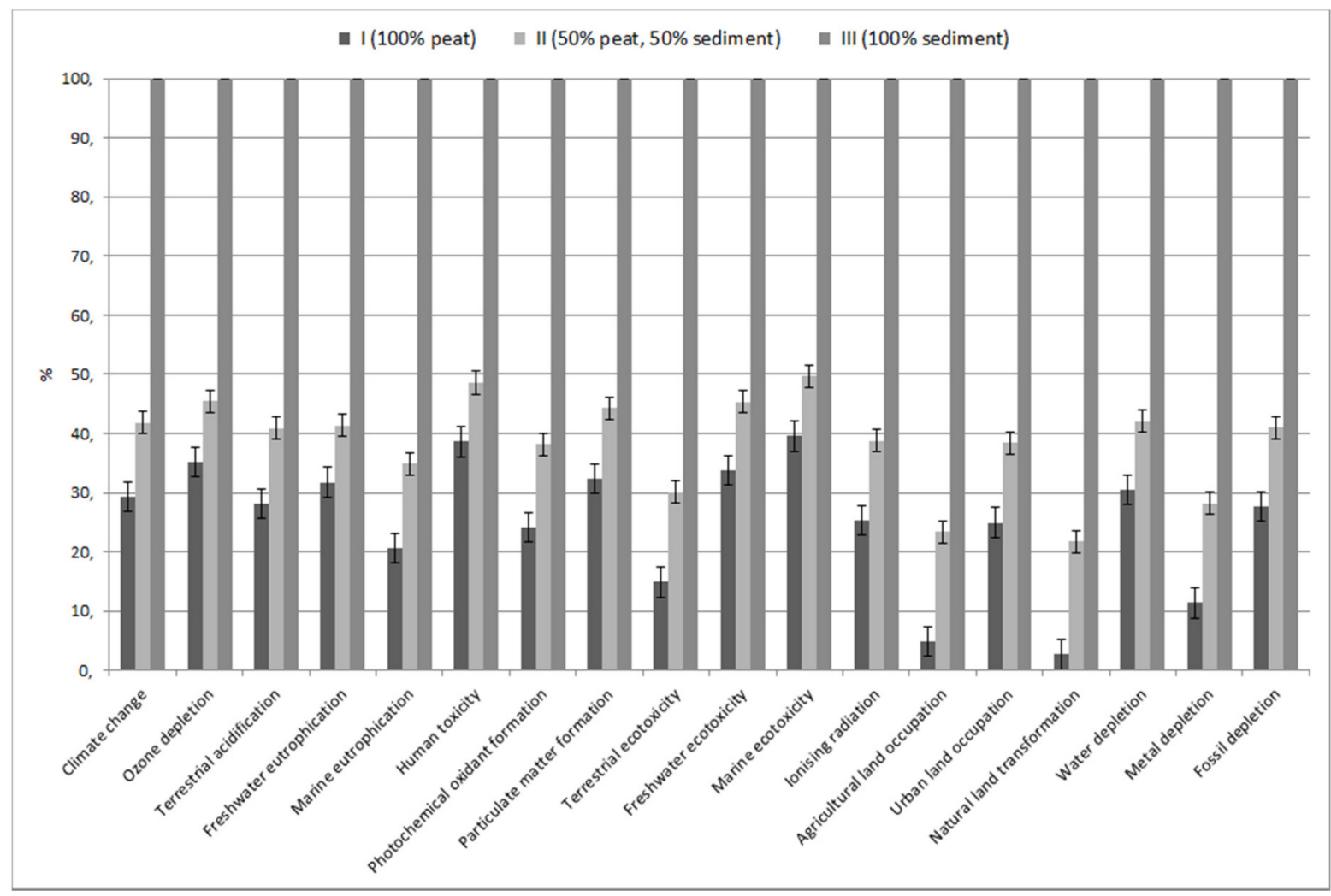

Figure 2. Comparison of the impact of the life cycle of the production of $1 \mathrm{Kg}$ of 'San Andreas' strawberry in three substrates.

Table 7. Process Contribution. Analyzing $1 \mathrm{~kg}$ 'San Andreas' strawberry grown in substrate II (SII). Method: ReCiPe Midpoint (E) V1.13/Europe Recipe E/Characterization/Excluding infrastructure processes. Unit: \%.

\begin{tabular}{|c|c|c|c|c|c|c|c|}
\hline Impact Category (IC) & Direct Impacts & Electricity & Lechate & Pesticides & Fertiliser & LDPE & SII \\
\hline Climate change (CC) & 0.00 & 18.44 & 0.00 & 0.00 & 35.89 & 28.46 & 17.22 \\
\hline Ozone depletion (OD) & 0.00 & 6.95 & 0.00 & 0.07 & 83.51 & 0.16 & 9.31 \\
\hline Terrestrial acidification (TA) & 0.00 & 16.28 & 0.00 & 0.01 & 41.34 & 21.83 & 20.55 \\
\hline Freshwater eutrophication (FE) & 0.00 & 0.00 & 54.78 & 0.01 & 22.55 & 1.90 & 20.77 \\
\hline Marine eutrophication (ME) & 0.00 & 2.47 & 0.00 & 0.01 & 66.05 & 3.82 & 27.65 \\
\hline Human toxicity (HT) & 0.00 & 2.78 & 3.53 & 0.01 & 56.76 & 4.90 & 32.02 \\
\hline Photochemical oxidant formation (POF) & 0.00 & 12.21 & 0.00 & 0.00 & 27.40 & 36.74 & 23.64 \\
\hline Particulate matter formation (PMF) & 0.00 & 13.01 & 0.00 & 0.00 & 38.18 & 19.78 & 29.02 \\
\hline Terrestrial ecotoxicity (TE) & 0.02 & 0.72 & 17.04 & 0.00 & 46.93 & 0.19 & 35.10 \\
\hline Freshwater ecotoxicity (FET) & 0.01 & 1.28 & 0.55 & 0.01 & 46.28 & 11.58 & 40.30 \\
\hline Marine ecotoxicity (ME) & 0.00 & 1.38 & 0.20 & 0.01 & 51.11 & 13.97 & 33.32 \\
\hline Ionising radiation (IR) & 0.00 & 33.39 & 0.00 & 0.01 & 29.08 & 0.06 & 37.46 \\
\hline Agricultural land occupation (ALO) & 0.00 & 0.17 & 0.00 & 0.00 & 14.09 & 0.05 & 85.70 \\
\hline Urban land occupation (ULO) & 0.00 & 1.61 & 0.00 & 0.01 & 51.65 & 0.29 & 46.44 \\
\hline Natural land transformation (NLT) & 0.00 & 1.76 & 0.00 & 0.00 & 6.86 & 0.03 & 93.10 \\
\hline Water depletion (WD) & 61.12 & 31.69 & 0.00 & 0.00 & 3.62 & 1.23 & 2.34 \\
\hline Metal depletion (MD) & 0.00 & 5.64 & 0.00 & 0.03 & 33.21 & 6.56 & 54.56 \\
\hline Fossil depletion (FD) & 0.00 & 11.96 & 0.00 & 0.00 & 23.04 & 54.47 & 10.53 \\
\hline
\end{tabular}

The leachate produced during the cultivation phase is the element that most influence freshwater eutrophication (FE) (89\%) and the variability of the composition of the treated sediment will be reflected in these indicators. For FE, the fertilizers contribute $22.5 \%$, and the substrate contribution is $20.8 \%$ (some from peat production $(16.5 \%$ ) and sediment $(4.3 \%))$. Torrellas et al. [16] reported lower EF results for tomato crop, however, it should 
be noted that in this study leachates are not specifically considered and analyzed because the cultivation occurs directly on the land.

The leachate contributes $17.04 \%$ to the total impact in TE (terrestrial ecotoxicity). Although the heavy metal content data of the sediments are within the limits established by the legislation [32], the use of starting materials that contain greater heavy metal content will be reflected in a greater impact throughout the entire production chain.

In climate change (CC), the production of fertilizers represents $36 \%$ of the total impact in this category, followed by the production of low-density poly ethylene (LDPE) $(28.46 \%)$ and the production of electrical energy (18\%). The substrate represents $17.2 \%$ of the total de $\mathrm{kg} \mathrm{CO} 2$ eq. The contribution to the impact by the substrate may be overestimated since the energy used in the sediment dredging from the port has been considered in its production chain in addition to phytoremediation and landfarming. It would be possible to allocate sediment removal charges to the port maintenance service and not to the mass of sediment used in GM production, which would result in a lower contribution of this sediment to the impact in CC. The contribution of the direct impacts of the cultivation phase to CC is null since, in this experiment, no machinery that burns fuel was used (this often occurs in commercial farms). In field production, the consumption of fuel and the emissions produced in the field due to the burning of fuel have an important contribution to this indicator [22].

In terrestrial acidification (TA) the main contributions (41.3\%) to impact correspond to fertilizers and the specific contribution of potassium nitrate production is $21 \%$. Poly Ethylene production (21.8\%), substrate production (20.6\%), of which $9.53 \%$ corresponds to the peat, $5.25 \%$ to the compost used in the treatment of the sediment and the rest to the energy used in the treatment of the sediment. Electric energy consumption during de culture phase (1.52 MJ/UF) represents a $16.3 \%$ contribution to TE. The results for TA obtained for strawberry are, in general, significantly higher when compared to other crops such as annual arable oilseed rape may be due to the cultivation system in camp and the higher production yield [33].

In the IC of ozone depletion (OD), the element that presents a greater contribution is the production of fertilizers $(83.5 \%)$, followed by electricity consumption in the cultivation phase $(6.95 \%)$. Although it must be taken into account that when applying the Europe E Recipe Normalization factors, this category has a much lower weight than categories such as FE, HT and ME.

To reduce the impacts of a growing medium, consideration should be given to changing the composition of the growing medium. Although phytoremediation is generally perceived as a sustainable green technology, like any agricultural activity, it can cause many environmental impacts, mainly due to harvesting [34], the application of fertilizers and pesticides, direct emissions [35] and biomass aftercare [10].

\section{Conclusions}

The study results confirmed that the environmental footprint of the 'San Andreas' variety strawberry is aggravated by the use of dredged remediated sediments from the port, mainly due to its effect on strawberry production. In this way, the lower production obtained from the plants grown in substrates with dredged marine sediment translated into greater environmental impacts per kilo of fruit.

In this context, and based on the results, it would only be recommended to use dredged remediated marine sediments in mixtures $(<50 \%)$ with other growing media to guarantee the minimum impact on fruit production and therefore reduce its environmental impact.

Other varieties of strawberries with a higher average and/or more stable productions can be studied, aiming to guarantee the minimum environmental impact in the reuse of dredged remediated marine sediments as a culture medium. Thus, additional studies will be necessary to select crop varieties and/or mixtures of phytoremediated sediments with different types of soil in which strawberry yield is equal or improved. 
Author Contributions: Conceptualization, P.L., F.H., R.M.-F., J.J.M.-N. and P.M.; methodology, and validation, P.L., F.H., R.M.-F., J.J.M.-N. and P.M.; formal analysis, D.J. and C.R.J.; investigation, P.M., P.L., F.H., R.M.-F., J.J.M.-N., F.T. and E.G.; writing-original draft preparation, P.M., P.L., F.H., R.M.-F., J.J.M.-N., F.T. and E.G.; writing-review and editing, P.M., P.L., F.H., R.M.-F. and J.J.M.-N.; supervision, P.M.; project administration and funding acquisition, P.M. All authors have read and agreed to the published version of the manuscript.

Funding: This research was funded by European LIFE Project, HORTISED, grant number LIFE14/ $\mathrm{ENV} / \mathrm{IT} / 000113$.

Institutional Review Board Statement: Not applicable.

Informed Consent Statement: Not applicable.

Data Availability Statement: Not applicable.

Conflicts of Interest: The authors declare no conflict of interest.

\section{References}

1. Bortone, G.; Arevalo, E.; Deibel, I.; Detzner, H.-D.; De Propris, L.; Elskens, F.; Giordano, A.; Hakstege, P.; Hamer, K.; Harmsen, J.; et al. Sediment and Dredged Material Treatment Synthesis of the SedNet Work Package 4 Outcomes. JSS J. Soils Sediments 2004, 4, 225-232. [CrossRef]

2. $\quad$ Lundberg, K.; Ohlsson, Y.; Andersson-Sköld, Y.; Bergman, R.; Falemo, S.; Edeskär, T.; Scheffler, A. Dredging Contaminated Sediments in the Baltic Sea-A Guide to Sustainability Assessment Tools; Le Comité Français de Mécanique des Sols et de Géotechnique (CFMG): Linköping, Sweden, 2013.

3. Masciandaro, G.; Di Biase, A.; Macci, C.; Peruzzi, E.; Iannelli, R.; Doni, S. Phytoremediation of dredged marine sediment: Monitoring of chemical and biochemical processes contributing to sediment reclamation. J. Environ. Manag. 2014, 134, 166-174. [CrossRef] [PubMed]

4. Ugolini, F.; Calzolari, C.; Lanini, G.; Massetti, L.; Pollaki, S.; Raschi, A.; Sabatini, F.; Tagliaferri, G.; Ungaro, F.; Massa, D.; et al. Testing decontaminated sediments as a substrate for ornamentals in field nursery plantations. J. Environ. Manag. 2017, 197, 681-693. [CrossRef] [PubMed]

5. Holm, G.; Lundberg, K.; Svedberg, B. Sustainable Management of Contaminated Sediments Gestion durable des sédiments contaminés. In Sustainable Management of Contaminated Sediments, Proceedings of the 18th International Conference on Soil Mechanics and Geotechnical Engineering, Paris, France, 2-6 September 2013; International Society for Soil Mechanics and Geotechnical Engineering (ISSMGE): Paris, France, 2013; pp. 3215-3218.

6. CEN CR 13456:1999. Soil Improvers and Growing Media-Labelling, Specifications and Product Schedules; Specifications and Product Schedules; European Committee for Standardisation: Brussels, Belgium, 1999; 50p.

7. Lazzerini, G.; Lucchetti, S.; Nicese, F.P. Green House Gases (GHG) emissions from the ornamental plant nursery industry: A Life Cycle Assessment(LCA) approach in a nursery district in central Italy. J. Clean. Prod. 2016, 112, 4022-4030. [CrossRef]

8. Altmann, M. Socio-Economic Impact of the Peat and Growing Media Industry on Horticulture in the EU. 2008. Available online: https: / / peatlands.org/assets/uploads/2019/06/ipc2008p160-164-schmilewski-socio-economic-impact-of-the-peatand-growing-media-industry.pdf (accessed on 26 May 2021).

9. Martínez-Nicolás, J.J.; Legua, P.; Núñez-Gómez, D.; Martínez-Font, R.; Hernández, F.; Giordani, E.; Melgarejo, P. Potential of dredged bioremediated marine sediment for strawberry cultivation. Sci. Rep. 2020, 10, 19878. [CrossRef] [PubMed]

10. Vigil, M.; Marey-Pérez, M.F.; Huerta, G.M.; Cabal, V.Á. Is phytoremediation without biomass valorization sustainable?Comparative LCA of landfilling vs. anaerobic co-digestion. Sci. Total Environ. 2015, 505, 844-850. [CrossRef]

11. QUANTIS. Comparative Life Cycle Assessment of Horticultural Growing Media Based on Peat and Other Growing Media Constituents; Final Report; Report prepared for the European Peat and Growing Media Association (EPAGMA); EPAGMA: Brussels, Belgium, 2012; Volume 41. Available online: https: / / www.warum-torf.info/download/comparative-life-cycle-assessment-of-horticulturalgrowing-media-based-on-peat-and-other-growing-media-constituents (accessed on 1 June 2021).

12. De Benedetto, L.; Klemeš, J. The Environmental Performance Strategy Map: An integrated LCA approach to support the strategic decision-making process. J. Clean. Prod. 2009, 17, 900-906. [CrossRef]

13. Audsley, E.; Alber, S.; Weidema, B. Harmonisation of Environmental Life Cycle Assessment for Agriculture; European Commision DG VI Agriculture: Brussels, Belgium, 2003.

14. Cerutti, A.K.; Bruun, S.; Beccaro, G.L.; Bounous, G. A review of studies applying environmental impact assessment methods on fruit production systems. J. Environ. Manag. 2011, 92, 2277-2286. [CrossRef]

15. Peano, C.; Baudino, C.; Tecco, N.; Girgenti, V. Green marketing tools for fruit growers associated groups: Application of the Life Cycle Assessment (LCA) for strawberries and berry fruits eco branding in northern Italy. J. Clean. Prod. 2015, 104, 59-67. [CrossRef]

16. Torrellas, M.; Antón, A.; López, J.C.; Baeza, E.J.; Parra, J.P.; Muñoz, P.; Montero, J.I. LCA of a tomato crop in a multi-Tunnel greenhouse in Almeria. Int. J. Life Cycle Assess. 2012, 17, 863-875. [CrossRef] 
17. ISO. ISO 14040:2006 Environmental Management-Life Cycle Assessment_Principles and Framework; International Organization for Standardization: Geneva, Switzerland, 2006. Available online: https://www.iso.org/standard/37456.html (accessed on 1 June 2021).

18. Todd, J.A.; Curran, M.A. Streamlined Life Cycle Assessment: A Final Report from the Setac-North America Streamlined Lca Workgroup; Society of Environmental Toxicology and Chemistry (SETAC) and SETAC Foundation for Environmental Education: Pensacola, FL, USA, 1999.

19. Mattei, P.; Gnesini, A.; Gonnelli, C.; Marraccini, C.; Masciandaro, G.; Macci, C.; Doni, S.; Iannelli, R.I.; Lucchetti, S.; Nicese, F.P.; et al. Phytoremediated marine sediments as suitable peat-free growing media for production of red robin photinia (Photinia $x$ fraseri). Chemosphere 2018, 201, 595-602. [CrossRef]

20. Mattei, P.; D'Acqui, L.P.; Nicese, F.P.; Lazzerini, G.; Masciandaro, G.; Macci, C.; Doni, S.; Sarteschi, F.; Giagnoni, L.; Renella, G. Use of phytoremediated sediments dredged in maritime port as plant nursery growing media. J. Environ. Manag. 2017, 186, 225-232. [CrossRef]

21. Blonk Milieu Advies. Life Cycle Analysis (LCA) of stone wool and coco fibre growing substrates for greenhouse production. In Tomato Production in The Netherlands; PRé Consultants BV: Grodan, The Netherlands, 2011.

22. Tabatabaie, S.M.H.; Murthy, G.S. Cradle to farm gate life cycle assessment of strawberry production in the United States. J. Clean. Prod. 2016, 127, 548-554. [CrossRef]

23. Melgarejo, P.; Legua, P.; Pérez-Sarmiento, F.; Martínez-Font, R.; José Martínez-Nicolás, J.; Hernández, F. Effect of a New Remediated Substrate on Fruit Quality and Bioactive Compounds in Two Strawberry Cultivars 'Effect of a New Remediated Substrate on Fruit Quality and Bioactive Compounds in Two Strawberry Cultivars. J. Food Nutr. Res. 2017, 5, 579-586. [CrossRef]

24. Tozzi, F.; Pecchioli, S.; Renella, G.; Melgarejo, P.; Legua, P.; Macci, C.; Doni, S.; Masciandaro, G.; Giordani, E.; Lenzi, A. Remediated marine sediment as growing medium for lettuce production: Assessment of agronomic performance and food safety in a pilot experiment. J. Sci. Food Agric. 2019, 99, 5624-5630. [CrossRef] [PubMed]

25. Doni, S.; Macci, C.; Peruzzi, E.; Iannelli, R.; Masciandaro, G. Heavy metal distribution in a sediment phytoremediation system at pilot scale. Ecol. Eng. 2015, 81, 146-157. [CrossRef]

26. Kemp, R. Energy Consumption of Marine Aggregate Extraction; Marine Estate Research Report Energy; The Crown Estate on Behalf of the Marine Estate: Landcaster, UK, 2008; ISBN 978-0-9553427-9-0. Available online: http:/ /www.marineaggregates.info/ images / publications / ei-energy-consumption-of-marine-aggregate-extraction.pdf (accessed on 26 May 2021).

27. Dijkman, T.J.; Birkved, M.; Hauschild, M.Z. Modelling of Pesticide Emissions for Life Cycle Inventory Analysis: Model Development, Applications and Implications; DTU Management Engineering, Department of Management Engineering, Technical University of Denmark: Lyngby, Denmark, 2013.

28. EEA EMEP/EEA. Air Pollutant Emission Inventory Guidebook 2013. Technical Guidance to Prepare National Emission Inventories; EEA Technical Report No 12/2013; EEA: Luxemburg, 2013.

29. IPCC. 2006 IPCC Guidelines for National Greenhouse Gas Inventories Volume 4 Agriculture, Forestry and Other Land Use; IGES: Kanagawa, Japan, 2006.

30. Wernet, G.; Bauer, C.; Steubing, B.; Reinhard, J.; Moreno-Ruiz, E.; Weidema, B. The ecoinvent database version 3 (part I): Overview and methodology. Int. J. Life Cycle Assess. 2016, 21, 1218-1230. [CrossRef]

31. Huijbregts, M.A.J.; Thissen, U.; Guinée, J.B.; Jager, T.; Kalf, D.; Van De Meent, D.; Ragas, A.M.J.; Wegener Sleeswijk, A.; Reijnders, L. Priority assessment of toxic substances in life cycle assessment. Part I: Calculation of toxicity potentials for 181 substances with the nested multi-media fate, exposure and effects model USES-LCA. Chemosphere 2000, 41, 541-573. [CrossRef]

32. Ministerio de la Presidencia Real Decreto 865/2010, de 2 de Julio, Sobre Sustratos de Cultivo. 2010. Available online: https: //www.boe.es/eli/es/rd/2010/07/02/865 (accessed on 26 May 2021).

33. Brandão, M.; Milà i Canals, L.; Clift, R. Soil organic carbon changes in the cultivation of energy crops: Implications for GHG balances and soil quality for use in LCA. Biomass Bioenergy 2011, 35, 2323-2336. [CrossRef]

34. von Blottnitz, H.; Curran, M.A. A review of assessments conducted on bio-ethanol as a transportation fuel from a net energy, greenhouse gas, and environmental life cycle perspective. J. Clean. Prod. 2007, 15, 607-619. [CrossRef]

35. Suer, P.; Andersson-Sköld, Y. Biofuel or excavation?-Life cycle assessment (LCA) of soil remediation options. Biomass Bioenergy 2011, 35, 969-981. [CrossRef] 